\title{
10 \\ On the word ked: The 'way' of being and becoming in Muyuw
}

\author{
Frederick H. Damon ${ }^{1}$
}

\section{Introduction}

This chapter describes the concept and practice of the major term ked in the Muyuw language, the principal language spoken on Muyuw, otherwise known as Woodlark Island, in the northeast Kula Ring, in Milne Bay Province, Papua New Guinea. The concept may be simply translated as 'path' or 'road', yet it abounds in sociological subtleties and cosmological foundations. It simultaneously formulates Muyuw's cultural specificity and orients people to a larger regional context. In facilitating these twined but opposed tendencies, the word is used in a pattern of social thought and action widely distributed throughout the Indo-Pacific. Although this contribution is confined to the northeast Kula Ring, ${ }^{2}$ it is lodged in a study of Asian-Pacific social histories and dynamics.

\footnotetext{
1 As always, the information in this chapter flows from the kindness and intelligence of my many Muyuw teachers over the years. Additional thanks must go to David Gibeault and Luo Yang, who facilitated important comparative understandings about the Chinese concept of daoltao; to Liang Yongjia for participating in that discussion; to Malcolm Ross for insights about the historical linguistics of the Austronesian languages of Milne Bay (he encouraged me to make an argument in this chapter); and to James J. Fox for his incisive comments on an earlier draft of this chapter.

2 I use 'Kula Ring' to refer to this place in Papua New Guinea and kula to refer to the institution and practice of circulating 'armshells' and 'necklaces' counterclockwise and clockwise around the island cultures participating in the institution. Kula is the Trobriand pronunciation of the word Małinowski made famous. The Muyuw cognate is kun. The word is used as a noun and a verb.
} 
When I commenced research in the 1970s, 'ked's' significance was apparent. One easily realised that its pedantic translation-'path' or 'road' - did not capture the complex nuances inherent in its usage. I was told precisely that by a Muyuw man pulled into the English-language orbit of the country still shy of its formal independence. One of a set of young men drawn from the island to receive Western training, he was, perhaps like me, struggling with the all-too-ready translation into English. ${ }^{3}$ With the spirit of that early encounter and with a world of different research behind it now, this chapter attempts to make apparent an important and allusive idea central to the organisation of Muyuw lifeways. I first examine words and their usage. I then turn to some of the origin mythology behind attempts to grapple with what at first seems like the idea's central content: the organisation of exchange. The operational understanding this affords brings the chapter to a conclusion. There I outline the structures by which the idea of ked becomes a manifold of complexity.

\section{On (the) words}

Words, things and people are said to go 'on' (wa-) paths, tracks, ked. The Muyuw word translated as road, or path, is a frequently heard and rich concept. 'Way', 'manner' or 'method' and 'meaning' are among the English words its usage conveys. Two words might sound the same but people will say they have 'different paths' (kweita ked). Ideally, paths should be 'straight' (idumwal)—characteristics often applied to a person's actions or 'intentions' (non, or nanon, a word that can also be translated as 'mind'). This is judged good. Being 'crooked' (kaydodog) or 'moving aimlessly', 'wandering around' (tapleileiy), brings a contrary evaluation and is a vice. Asked how a person runs this or that kula relationship, the respondent usually says they just go on it, 'follow the path' (kikun ked), implicitly straight - an intention sometimes signalled with the movement of a hand, going out from the speaker, not to his side. This is not, however, a passive construct. It is as metaphysical as it is literal. People often speak as though the ked determines their action; they are just doing what the way prescribes. In this framework, the ked is the agent; people are just the means by which

3 Named Naudekon, he was a son of Molotau, the most important person in the northeast Kula Ring, if not the whole ring itself. Elsewhere (Damon 1983b), I have given an account of Molotau's extraordinary life objectives. Naudekon brought the word and its myriad possible translations into English, among them 'way' and 'meaning'. His realisation of the word's significance, like his father, I have always remembered. 
its action is accomplished. The stress here is not unlike that for the Chinese

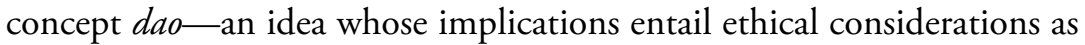
well as deliberate, straight intentions. ${ }^{4}$ A mortuary practice exemplifies the control ked holds over people. A death is likened to a tree falling, blocking paths among the living, who are connected by lines of affinity or kula (see Damon 2017:351n.24). People should ignore one another until they have performed a small clearing ritual. Good friends might walk by one another on a dock only a few feet wide because their 'path' was not yet opened. Another epoch in anthropology would understand this behaviour as rationalisation. Informants' descriptions, and some observations, of transactions of kula valuables and pigs would seem to support such an assertion - where the invocation of ked rationalises interests left unstated (but hardly unknown). However, I believe the idea comes instead from the acute sense of the social, of hierarchy, which the idea of ked carries in this region. By focusing closely on the words - in part, their grammaticalitythis section begins to explore this complex concept.

If, as is likely, the idea translatable by 'road', 'path', 'way' and 'manner' is important throughout the Austronesian world, the Muyuw—and very likely the greater Milne Bay region-word form ked is relatively specific. Green and Pawley (1998: 61) use *zalan as the Proto-Malayo-Polynesian term and *jalan as the Proto-Oceanic word for 'path'. These forms seem to be realised as dalan in Timor's Tetun language, ${ }^{5}$ hala in Tonga, sala in Rotuman and ara in Māori. In the Motu language along Papua New Guinea's southeastern coast, the form is dala; that it might be cognate with an important northern Kula Ring term-dala in the Trobriands and dal in Muyuw, which are terms often translated as 'subclan'—raises possibilities with which I end this section. The Muyuw term ked, the Trobriand keda and Dobuan eda all seem unrelated to the *jalan construction, according to the linguist of the Papuan Tip languages, Malcolm Ross (Personal communication, 31 December 2018). Ross surmises the word:

$4 D a ̀ o$ (道) is written with two characters. The lefthand character, chuò, translates to something like 'go' or 'movement'; the righthand character, shǒ u, translates to 'head' ('Motion by reasoning?'). The term expands into tiān dào (天道) and dàodé (道德). The first is like natural law; the second, ethics or morality. Y, chi and 'straight' (直, $z h i$ ) compose the dé from dàodé. Some months before this essay became well conceived, I asked Mark Mosko if he had considered the Chinese dao for his analysis of Trobriand ethnography. His response was that the title Way of Baloma intended just that. 5 Therik does not put dalan as such in his glossary. See bein ('ancestors') and bein dalan ('ancestor's path') (Therik 2004: 286). 
comes from *keja 'path', which is of Proto Papuan Tip antiquity, although of fairly restricted distribution ... It also has cognates in some Ngero languages - the languages of [the] Vitiaz Strait trade network. This makes sense, as Proto Papuan Tip seems to have come from the area, presumably in Lapita times'. (See also Pawley and Ross 1995: 59)

If Ross's speculations are correct, the word form perhaps reflects a synthesis between the region's original inhabitants and East Asian Austronesian currents over the past 1,500-3,000 years.

Although the word ked may participate in non-Austronesian language conventions, it shares common Austronesian/Oceanic possession usages. In simplistic terms, ked is a noun; its possession is telling. Three affix systems indicate possession in the Muyuw language and, by widespread understanding, the three classes are 'distant', 'intermediate' and 'intimate'. ${ }^{6}$ The first two are prefixes, the third is a suffix. Ked is possessed with a prefix, placing it in the 'distant' class. One says gunaked ('my road'). By contrast, 'my leg' would be kakeig, the suffix ' $g$ ' indicating the first-person intimate class; kakeim is 'your leg', the final $m$ being the possessive marker. Using the intermediate first-person possessive to say 'my leg' (agukakein) changes the meaning to the leg of a pig - a prestation received in a ritual, for example. Arguably, the possession classes have semantic significance. And the received interpretation of these matters is that they demonstrate qualities of inseparability/separability or inalienability/alienability. Most body parts use the 'intimate', 'inalienable' possessive form, indicating that they are internally related to a larger whole. By contrast, the 'intermediate' designation given in the example of 'my leg' - a piece of pork received in a ritual —specifies something separable and specifiable, individualised in its usage; this kind of debt to this actor, another kind from the same pig to a different person.

Although revealing, the paradigmatic differences the separable/inseparable contrast indicates ignore a processual organisation evident in practice. This leads us, not coincidentally, to the complexity in the Muyuw category ked. The word form ked is not just in the most separate, distant class, it is also in a class best characterised as tool-like. Included in this

6 Blust (2009: 476-84) uses 'direct' versus 'indirect' for the inalienable/alienable or intimate/ intermediate/distant distinctions I deploy here.

7 This is probably a generalisable point for Austronesian cultural forms. See Mosko (2017) for his transformation of a well-understood Austronesian classificatory scheme, 'base'/'tip', into the sequence base-trunk-tip-fruit. 
classification are axes and knives, a class of kula valuables (-kitoum), boats and, among others, individual fingers. Although the generic term for 'finger', didi-, takes the intimate suffix possessive, individual finger terms are possessed with the 'distant' prefix. This condition may speak to a no longer practised tradition that involved lopping off a digit for mortuary practices. Far more important, however, are the uses of individual fingers for fundamental tasks such as tying, weaving, handling and holdingthat is, producing things by digitally transforming certain potentialities into others. Arguably, the experiential structure of this understanding is built into annual and life cycles - that is, basic features of organised consciousness, as I have suggested for learning processes entailed in string figure usage in Muyuw (see Damon 2017: 286-87). Words in this class stand out because they make things, including people.

Details about the kula show the processual, sequential quality to the possession system. Ked is the fundamental term used with respect to kula relationships and, as noted, it is possessed by the distant possessive structure-so, gunaked for 'my path'. Kula valuables travel on these relationships and they are possessed with the so-called intermediate possessive: agumwal, aguveigun, for 'my armshell, my necklace'. The exchange of these forms creates a person's ranked 'name' and the word taking the suffix form of the 'intimate' class; hence, yagag for 'my name', with the closing $g$ the first-person indicator. ${ }^{8}$ Although an individual's name is an aspect of an inseparable identity, its value, its rank, depends on the state of affairs of kula valuables, and that follows from the travels of specific 'armshells' (agumwal, 'my armshell') and 'necklaces' (aguveigun, 'my necklace') on specific paths, -ked.

A similar sequence is evident in the terms used to specify kinship relationships. Among all of the terms in the 'distant' class are words translated as 'husband' and 'wife': mwan and kwav. 'Husband' and 'wife' are understood as part of a sequence - that is, a process that transforms this or that into something else. ${ }^{10}$ These two categories generate the affinal

8 This sequence is also indicated with the individually owned kula valuable called kitoum, which is in the 'distant' class. Hence gunkitoum-agumwal-yagag for 'my kitoum-my armshell-my name'.

9 As I have noted in other publications (Damon 1983a; 1990; 2017: esp. pp. 167-68), these categories have to be achieved on the basis of position-appropriate action. The categories exist as modes of action.

10 I discuss the metaphorical use of kinship terms with respect to yams, how a 'husband' (male yam) and 'wife' (female yam) are transformed into alternate generation relationships ( $t a b u$-) between a dried up old seed tuber and new yams, for eating or planting (Damon 1990: 167-68). Proximate generation relationships are conveyed by taro. 
relationship sinvalam. This form uses the intermediate possession classifier; one says agusinvalam, inasinvalam for 'my affines', 'his affines'. By the operation of this relationship (the word can be made a verb, especially with a causative construction like $k a b i$-), people are made and with them emerge relationships specified by other kinship terms, most of which are in the 'intimate' class. First and foremost among these are proximate generation in-laws, yawa-, and the brother-in-law category, nubou-. As noted elsewhere (Damon 1983a; 1990: Ch.4), almost all ritual activity in Muyuw centres on relationships defined in reference to these terms, the $k e d$, the manner or way appropriate to the designations. For example, as soon as a young man is seen to be married, he should go to his in-laws' (yawa- or nubou-) garden to work (if in a sailing village, to their boat); a young woman should carry firewood to her husband's female yawaand yava $-t$, more or less a new bundle every day until she has gifted everyone. And by their interaction flow all those positions following from the productive activities of married couples, 'father'/'mother' (including mbw)/'child' (tama-lina-/natu-), MB/ZC relationships (kada-); 'alternate generation' relationships, which include FZ/BC relations (tabu-); and same-generation relationships, the same-sex sibling terms, es/ys, tuwa-l bwada-, and the cross-cousin term nubie- ${ }^{11}$ Apparent anomalies to this synthesis are the terms for opposite-sex siblings and the sister-in-law relationship, respectively, $n a-t$ and yava $-t$. In these, the possessive is infixed. A woman would refer to and sometimes call her brother nagut and her sister-in-law yavagut (both reciprocals). It may be noted that the same possessive anomalies appear in Trobriand kinship terms. If the infixed possessive $-g u$ - in this structure suggests this form contains qualities exemplified in the spousal terms-gunakwav and gunamwan-then this is consistent with affinities that exist between brothers and sisters and husbands and wives; for example, relations between both should not be visible in public. Mosko (2017) has featured this in his recent accounting of Trobriand kinship. The yava $-t$ term arguably participates in this form because of specifications concerning the production of children. Muyuw understand that men make children because they produce the food women convey to them in utero and ex utero. By virtue of this claim it is held that men control their children. And, after a father, his sisters (or a still dominating mother) have the next most important say over a child's

11 The Muyuw kinship terminological system is nearly identical to the Trobriand set except with regard to cross-cousin terms. In the Trobriands, FZC is tabu- and MBC is latu-. Muyuw believe that cross-cousins marry in the Trobriands, unlike in their own system, where they are not supposed to marry. 
fate (first and foremost concerning marriage). Although these claims are realised in ritual action running through the life cycle (described in Damon 1989, as well as 1983a and 1990), they are symbolised in a little gift right after a baby is born. This gift is the child's first excrement, which is wrapped up and given to the father's sister as a testimony to her claims on his productivity. ${ }^{12}$

All the patterns implied in the foregoing are connoted by the word ked; different relationships have different ked. This speaks to the sociological subtleties fixed in the term. It contains complex ideas and subtle action. Here I note one other usage of the word and then conclude this initial section with several domains of action that might be understood in similar terms.

\section{A derivative of $k e d$}

Although a different word, $k u t$, is used for a boat's course, a modification of ked specifies narrower passages boats follow when passing through reefs. The term is aniked. A more than metaphorical use of this term is sometimes applied to the movement of gardens/fields over time. Muyuw practise a version of slash and burn agriculture, yet forests are not randomly cut for new fields. In addition to different regions having different ideal fallow lengths designed to produce different tree products, garden spaces move around plots of ground called tasim, ${ }^{13}$ which are plots of uncut forest. These groves are so defined because they have more coral than dirt. This is not, however, just a negative because tasim generate important forest resources as well as conceived favourable ecological conditions for adjacent fields (see Damon 2017: 132-39). The courses a garden takes around tasim over time may be called aniked, as if a garden is a boat passing over the forested coral-strewn land like a real boat pilots through passages in reefs. Gardens have boat terms imposed on them and the language of sailing, or paddling, suffuses garden work. The aniked usage is part of a rich set of reciprocating understandings between the land and the sea (and sky) — understandings fixed in cosmological constructs.

12 This approach to kinship terminologies adopts a 'production' rather than 'exchange' perspective, outlined in Damon (1983a). Piot (1991) deploys this approach in West African Togo.

13 Muyuw say that the word tasim derives from their word for island, sim, and the word for chop, tay. 


\section{'Subclan' as the Proto-Oceanic 'path'?}

The Motu cognate of the Proto-Malayo-Polynesian term ${ }^{*}$ zalan and the Proto-Oceanic word *jalan for 'path' is dala. I conclude this section by exploring the possibility that these proto forms may be behind concepts and practices anthropologists have used to describe what are called 'subclans' across the northern side of the Kula Ring. To what extent might it be accurate to understand 'subclans' as paths, as sequences?

The Muyuw word is dal; the Trobriand, dala. This term contrasts with kum in Muyuw and kumila in the Trobriands, which is usually translated as 'clan'. Dalldala are inside of kum/kumila. Conventionally, both are understood as matrilineal units. There is an indeterminate number of dall dala. Trobriand dala are ranked. Muyuw dal are not ranked, though they may gain or lose stature as they gain or lose resources. There is a fixed number of kum/ kumila: eight in Muyuw, four in the Trobriands. Everyone west of Muyuw - that is, from Gaw through Iwa and Kitava-proclaims that Muyuw people 'lie' when they assert there are eight. ${ }^{14}$

The container/contained logic employed with these categories allows Muyuw people to sometimes use the category kum to invoke what they really mean by dal. Possible ambiguities in this usage may be easily disambiguated because, in a formal sense, the clan idea, kum, specifies marriage relations - a very specific kind of ked-but does not contain property. By contrast, the subclan idea, dal, does not specify marriage relations with other like units but they hold property. Similarly, although people may speak of the actors in mortuary rituals as clans, kum, in fact the real actors are members of a specific subclan, dal, and these are the units that hold the debts or credits created in ritual action and the resources attached to those debts/credits.

Representations in space create the principal ways by which Muyuw kum (clan) and dal (subclan) ideas are understood. Muyuw gardens must be configured by at least two paths, with the idea of kum located at their

14 'Lie' (yaweid) covers a range of ideas that go from 'mistaken' to 'lie' in English. Muyuw distinguish between the 'old' kum, which are the four to the west, and 'new ones', two of which in fact play roles as dala on, for example, Iwa. Eastern and central Muyuw tended to become embarrassed when asked why they had eight clans; some muttered about incestuous ancestors. In western Muyuw, a well-known myth tells of people from the Kwasis clan building a tower to the heavens. The tower collapses and the fallen members turn into the new clans. 
intersection. ${ }^{15}$ Ideally, one path goes 'sunrise/sunset' - from east to westand the other bisects it, going by what Muyuw call bomat/yals, which is more or less 'north/south'. ${ }^{16}$ The four 'old clans' are positioned around the garden intersection east (Malas), west (Kubay), north (Dawet or Kulabut') and south (Kwasis). These directions stipulate reciprocal marriage relations, which are customarily spoken of as if women are exchanged between the clans/kum; people can and do also think of them exchanging men. This construct is a ked. In it the genders are separated.

In contrast to kum, dal (subclans) are distributed over the landscape, including locations far beyond Muyuw, and almost invariably individually rather than as part of a set of relations. These spaces are the antithesis of the organised garden form in which kum are set. And although the first emergence points are said to be part of a dals property, ${ }^{17}$ usually they are the opposite of productive resources such as garden land, sago orchards and so on. Among the listed emergence points-which in fact are often very vague - are mountain tops, small islands (some far from Muyuw, others close by), swamps and unspecified beaches. They are called mumugw, which is a duplication of the word for 'lead', mugw. Very few Muyuw, however, profess to know very much about their 'origin stories' (taleliu). Yet everyone presumes that a brother and sister were together under the ground. They came out, emerged (kapow) and then separated to be where they are today. As the social relationship in that underground abode is virtually an incestuous, negative reality, so is the property an antithesis. Only when they separate do you find people where they are now, married and with their dal possessing real entities, totems, names

15 The garden form is the culture's most elaborate formal model, discussed in detail in Damon (1990: Ch.4) and Damon (2017: Ch.1).

16 In 2017, I learned that this coordinate also follows the Milky Way in the early evening darkness of June, running more or less east-west. Correspondingly, the line bisecting it follows, though not as exactly, the swing of the Milky Way in the early evening of, approximately, December, when it is oriented northeast/southwest. This is a significant addition to the ethnography of this region and will require much new research (see Damon 2018). Although east-west-north-south are relatively accurate representations of the Muyuw categories nuvid-yavat-bomat-yals as idealisations of wind directions, such an understanding does not prevail in Iwa, to the west, nor in Gaboyin, which is an important island in the Kula Ring to Muyuw's south. Mosko (2009: 507n.6) provides Trobriand direction names, some of the terms for which are equivalent to those just listed, but the directions Mosko claims they specify differ.

17 There is pressure to make dal origin stories deeds to owned land. Dividing royalties from logging and mining have been principal forces behind this movement. About half of the people in Wabunun came out of the ground at Kavatan, along Muyuw's eastern flank. Some of those people wondered whether they would be moved back there. In 1996, the people who lived in Kavatan-none of whom was a member of that subclan-feared they would be removed from the only land they have ever known. 
of significant boats, garden land, sago orchards and, increasingly west across the Muyuw landscape towards the islands of Gaw and Iwa and eventually the Trobriands, sets of personal names. In Muyuw, this real property is a function of the state of (usually pig) debts between subclans. ${ }^{18}$ Unlike the intervals between the emergence place and present locations in space, the state of credits and debts between subclans is specifiable and is the primary, though not overtly public, point to the exchange of pigs in the culture's primary mortuary ritual (sagal or, more definitively, anagin tavalam: literally, 'fruit of our crying').

These facts are consistent with the idea of a subclan as a path through time. Abstractly and vaguely, this path is from the origin point to people's present locations. If the (imaginary) origin spot can be pinpointed, present locations can be very diverse. A dominant subclan in Wabunun thinks it has representatives in Misima, Nasikwabw, Waviay, Kaulay and Kawuway, Gawa, Iwa and, I believe, Sinaketa in the southern Trobriands. In principle, real dots connect those lines; in fact, Muyuw people do not keep tract of such relations. Yet it would not have occurred to me to consider the subclan category dal to be related to ${ }^{*}$ zalan as the ProtoMalayo-Polynesian term and *jalan as the Proto-Oceanic word for 'path' or the Motu dala but for one recently learned set of facts. In Muyuw, distinct varieties of sago are also called dal. A unique named sago orchard, for example, will have many different clumps of growing sago, usually with one in each group much taller than the others; the latter bud off the former. People name the different varieties, calling each one a different dal. An orchard might, for example, have 20 different clumps, but only two or three or four varieties - that is, dal. People insisted this dal was the same word used for what I call subclans. One woman, sitting on a step with her daughter perched between her legs, said that just as a sago plant buds off its mother, taking over its position, so does she give birth to her daughter so that the unit continues. They create a sequence. The 'path' here is an abstracted time concretised through birth rather than a finite space, which is much more the case with the ked usage. Muyuw do not believe in reincarnation. A deceased person's 'soul' (kaluan) goes to Tum and never comes back. By contrast, in the Trobriands, ideas about reincarnation are well formed and, in Mosko's work at least, dala are an

18 I have touched on these procedures in many places (Damon 1983a; 1989; 1990: 94-118; 2017: 152-53). 
elaborated construct running the course between Boyowa, this land, and the after and before-life in Tuma. The idea is profound and is much more road-like. ${ }^{19}$

\section{On origin myths}

A central component of Western cosmology is that Western societies developed from an original primitive and, in Durkheimian terms, mechanical form to the organic, highly differentiated form they have today. ${ }^{20}$ Muyuw origin mythology is different. They understand the form of their culture being defined by a creator called Geliu. Shehe to some-comes to the island by boat, organises the local practices and then goes on to the west. I was told I had to go to those places to understand what Geliu did there. For a long time, it was convenient to take that information as a limit; over there was another social system. Only in the course of doing research realised in my ethnobotanical study (Damon 2017) was I forced to take such data as the reciprocal of an essentially organic view of the world. In 1996, I was shocked to discover that people on Iwa Island did not know the names of much of the taro and yam they were planting; somewhat huffily, I was told that if I wanted to know that information I should go to Muyuw. Only much later did I realise that this was a division of labour created around the expected consequences of El Niño-Southern Oscillation (ENSO) events, called 'big suns' in the region. People know that Iwa's circumstances-as a small uplifted island with a meagre underground water lens easily exhausted by drought-mean it will lose its root crops during an ENSO event. Consequently, it falls to others to know the details of these means of production. People on other islands keep Iwa supplied with yam and taro seeds in exchange for its services-the nuts from several tree species that survive the droughts. The same conditions prevail on nearby Gawa and Kweywata islands-islands sculpted to produce the trees needed for large outrigger canoes.

19 So, also, are the 'stories' (leliu) Trobriand people know about the intervals between the origin point and the present. Muyuw complain about how little they know compared with Trobriand people, sometimes coming back from an encounter with a Trobriand person filled with stories ostensibly about their own identities.

20 In complex ways, 'exchange theory' in anthropology and its single-site long-term fieldwork methodology contributed to the problem I allude to here. 
It is in this context that the idea of paths ( $k e d)$ must be understood as a consideration encompassed by wider totalities just as it becomes clear that formulations in any one place speak at best to part of a set of discontinuous but interlinked structures. I will review this orientation with the exchange of shell-wealth concerned with kula; a similar argument could be made with respect to the exchange spheres in the domain of kinship but for reasons of time and space that argument must rest inside the concluding section of this chapter. ${ }^{21}$

Practically every time I started a conversation about the kula with a new informant, they broke off my question to make sure I understood the whole institution. They would list all the major social units through which it ran, always defining the customary circle of islands - those depicted on maps since Małinowski's Argonauts. The idea of the kula ked first entails a holistic view of the valuables circulating around the Kula Ring's two circuits: mwal (armshells), going from left to right, and veigun (Muyuw's generic term for the necklaces), going from right to left. Some of my sources were men who then had little stature in the institution. Significant players readily defined specific important ked by name of person and often their spouse and home village. One informant demurred on the last when he got to Dobu because he knew they practised what we understand from Fortune's work as bilocal residence; he did not keep up with those movements from, ideally, one year to the next.

This macroframe of reference is realised in the formal terminology used for specifying acting agents, by the way valuables are discussed and in the way names circulate on the backs of valuables. Inside these general orientations every participant has to know at least two people on his immediate left and right, and successful actors are likely to be able to specify a complete ring of actors in their larger relationships. I turn to these matters shortly.

21 Although I have not researched this material intensively since my original time in Muyuw (1973-75), I have made casual inquiries about various matters on each of the 11 times I returned to the island between 1982 and 2017. During these returns, I sought information about the travels of the five large mwal that defined most kula activities between 1973 and 1975 (Dayay, Nimov, Kunakwan, Mantasop and Tuidaman). In 2017, I rehearsed a manoeuvre I described in Damon (1983c: 332-34) to see whether my understanding still seemed accurate; it did. 
This level of knowledge, however painstaking it is to first acquire, gives an incorrect understanding of what kula ked are. Synthesising the gift literature in the mid-1990s, Godelier opened up an important level of analysis when he argued:

[I]n analyzing a gift, whatever it may be, one needs to consider the relationship that existed between the giver and the receiver before the former made a gift to the latter. (Godelier 1999: 13; emphasis in original)

What follows from this for the Kula Ring concerns the tiers of knowledge people have of the villages and islands around them. This knowledge is both detailed in a particularistic manner and encompassed by means of various cosmological and geographical, almost geological, orientations. This knowledge system approaches in form the likes of that which one may intuit from Chinese materials totalising 'China' from ancient times (Pankenier 2013). ${ }^{22}$ The particulars quickly speak to the real or created ecological differences in the region-facets that become organised in subsidiary kula exchanges. Well-known ones concern Budibud, to Muyuw's southeast, being planted with coconut trees long before copra plantations were enforced on the region. Budibud's coconut palms were turned into coconut-leaf skirts, coconuts themselves and pigs-all of which, along with the region's high-quality pandanus-leaf sleeping mats, were traded to Muyuw for sago. Although the sago was a matter of daily consumption for its Budibud recipients, Budibud products were often used to capitalise productive relationships in Muyuw. Many Budibud coconuts and pigs went into Muyuw mortuary rituals, all of which had to do with subclan resources noted in the discussion of dal. Budibud skirts and sleeping mats often were-and, in the case of mats, remainshuffled into kula relationships, sometimes being exchanged for clay pots from the southeastern corner of the Kula Ring. To Muyuw's southwest is the volcanic cone of Yemga, amid an almost classic coral atoll structure. A small sailing community without enough land to support itself by horticultural pursuits, Yemga trades its seaside life for vegetable products from Yanab on the northern side of its atoll structure and virtually all of the villages across Muyuw. Most of that seaside life concerns the outrigger canoes it maintains as one of the principal sailing villages coordinating travel between the northeast and southeast corners of the Kula Ring.

22 See also Granet (1973: 47) as well as recent explorations of classical texts (Dorofeeva-Litchmann 1995). 
But it also concerns a fish, papis (perhaps Siganus argenteus), that schools right off its sandy beaches. Now and again, hundreds of these fish will be caught, smoked and taken to Muyuw as prestations for vegetables; these exchanges are specifically designed to feed into the kula. These are not incidental exchanges, but are rather fixed in the region's social organisation. As noted elsewhere (Damon 2017: 165-74), there is a system using ritual firewood marking differences among and therefore relations between places. In most rituals, only this wood should be burned, and a significant affinal responsibility for women entails knowing which trees should be given in the appropriate context. Although not everyone knows all the wood for every place, most know about the practice. In my published account, I did not list Yemga's wood because I did not then know it. In 2017, I learned it was mwadog (mangrove). As in all the other cases, this tree speaks to Yemga's specific situation-nestled along the shoreline as it is. Although individual trees can be harvested for ritual purposes, the grove must be maintained to protect the island from the occasional 'big wave'-presumably, tsunamis. Other villages' trees mark other specific orientations. The tree for several southeastern villages comes from early fallows because those villages use fallows of that age for growing food of a certain quality and generating hundreds of species-specific saplings for outrigger canoes-canoes usually owned and operated by other sailing villages.

If ritual firewood knowledge reflects organised consciousness one level up from the pragmatics of specific exchanges, land names and real or mythical histories entail another level. The identity of Nasikwabw, another sailing village south of Muyuw, is bound up with the idea that part of its heritage derives from Misima, an island east of the southeastern corner of the Kula Ring and outside the immediate flow of kula valuables, but inside the limits of the current social system. People say that Misima people first came to Nasikwabw to make their living - a time evinced by a scatter of potsherds and chipped stone. But while perched at Nasikwabw's eastern end one day, people saw the Sulog Mountains to the north, so the pot and stone-tool works moved there; Nasikwabw mediates between Misima and the stone-tool industries once located on Sulog. Iwa, the little island dot that stands almost exactly between Muyuw and the Trobriands, has its northeastern/southwestern axis defined by a myth that orients that place exactly to its social connections to those very directions. Liluta is the name of an important Trobriand village and also of a plot of garden ground to the west of the important central Muyuw village of Kaulay. Although 
I was surprised by that 'Trobriand' name amid Kaulay's territory, my Kaulay informants were not and added to the seeming coincidence that implanted near the Trobriand Liluta is a piece of igneous stone derived from Mount Kabat, the tall mountain to the south of Kaulay and the source of standing - or fallen - stones that demarcate the travels of the ancestors who created standing stones and stone ruins scattered about the landscapes of Kaulay Gawa, Iwa, Kitava and Kiriwina. Following Strathern's (for example, 1988, 1991) work, Mosko (2017) demonstrates the pertinence of the partible person idea for Trobriand sociality, showing how much Trobriand reality has to do with passing qualities from one person to another. But it is not just people who are understood as composites here; by complementary exchanges, mythical stories and land names, islands are understood in the same way.

One learns about this information as almost incidental, and, in my case at least, as tangents to other questions. However, there is reason to believe they are fundamental, not tangential. In 2017, a Yemga man recounted a myth about the beginning of the kula. It concerns a snake on Goodenough Island, beyond the southwestern corner of contemporary kula flows. The snake gives birth to a woman, who in turn has a daughter too anxious to see her grandmother. When she does the snake becomes angry and runs away, with a mwal on one side of its mouth and a veigun on the other. It first goes to Rossel Island at the very southeastern end of Milne Bay. It leaves the veigun there as Rossel Island's work. It passes on to Yemga, where, among other things, it makes the fish noted above, papis, Yemga's work and, because of another altercation, makes the island of Yalab like a snake. Thence it goes to Kilivil, the Trobriands, where it leaves mwal as their work. My source told me that originally Muyuw was not in the kula, but because Muyuw had sago it was eventually incorporated. ${ }^{23}$

Myths like this one are, of course, just stories. But the truth they contain is that of an organised consciousness that probably has more layers than usual anthropological knowledge manages to circumscribe. And there is no reason to think that any one point in a social system is going to encompass all of the knowledge necessary for its functioning, just as it is reasonable to assume that the villages lying to the Kula Ring's southern borders are going to have cultural openings to regional relations

23 I do not recall hearing this myth earlier. In the autumn of 2017 , I repeated the story to Professor Maria Lepowsky, who did research in what many people know as Sudest Island, Vanatinai. She recounted a much fuller version. For some, it is a well-known story. 
external to the institution. Indeed, over the past decade of my visits to the area, I have become aware of a peculiar geographical model, the full implications of which remain unclear. Many Muyuw people claim that Rossel Island is the highest island in the region while the Trobriands are the lowest. This geographical understanding inverts the social standings of the respective areas: Trobriand hierarchy is legendary, as are the lack of status and indeed apparent isolation of Rossel Island. When I asked people where Muyuw and Goodenough stood in this ordering, I was told they were about the same, between Rossel and the Trobriands. At least some of the people who reported these facts also know that they are not a literal description of reality. Although the Trobriands are among the lowest islands in the region and Rossel's peaks, at about 840 metres are taller than Muyuw's (perhaps 350 metres), Goodenough towers over all of them at more than 2,500 metres. Going along with the precise geographical model of all the islands in the region-on a southeast to northwest axis, geological and social elevation invert one another-is the fact that all islands are conceived to be correlated with, if not under, specific stars. This order of facts has to do with navigational models, but it nevertheless implicates well-formed models about star locations, island locations and relations among these. Ked operate within social conventions organised by complex structures. ${ }^{24}$

\section{Conclusion: On the structures}

The idea of ked - an operation among agencies in the form of people and their places-exists inside a complex of semantic spaces. This complex space is why people speak as if ked determine their actions. For different purposes, I have described many of the pertinent details of these forms elsewhere (Damon 1980a, 1980b, 1983a, 1983c 1993, 2002). Here I argue that the idea of a ked is a diacritic establishment of a set of relationships manifesting a social field. The idea organises ranked intentionalities. I start with kula exchange, illustrate the ordering of relationships in the domain

24 In a recent archaeological synthesis of the kula region, Irwin et al. (2018) create a picture of, on the one hand, near-Lapita origins for the region and, on the other, the recent emergence of the order we have known from Małinowski over the past several hundred years. The image of chaos in their model fits one of the versions Muyuw have of their own history: until the Europeans arrived, there was nothing but fighting, no villages, gardens, kula or anything else. Slightly more detailed versions of that chaos argue that the fighting took place between 'villages' (ven) organised into two groups, and in the 1970s, elders easily divided every village I could name, on Muyuw and other islands, into one of these two moiety-like groups (Damon 1990: 70-83). 
of kinship and conclude with a description of procedures for asking for things - the order of metonymies in the request forms illustrative of the kinds of totalities that make up this social system. These forms return us to this contribution's East Asian framing.

Each ked has its own form. A kula relationship could start with innocent exchanges of betel nut for betel pepper between young people who barely know one another. One gives the other nuts to chew; the recipient reciprocates with pepper. The two different things are combined and, as talk flows, they begin to learn about each other. Nobody more need be involved. But time may turn that simple encounter into the exchange of low-ranked kula valuables. Kula relationships, however, are not dyadic. If the details of a particular valuable are not already known, they are figured out. And the information has a grammar. If $\mathrm{C}$ wants a valuable from $\mathrm{D}$, he must know or will ask whose 'hand' it is. D must answer by specifying not his partner's name, E, but the partner of his partner, F: 'F's hand' is the answer to the question 'whose hand is it?'. In Muyuw, immediate partners are called veiyou-, which is the same word used to refer to clan/subclan members. Partners of partners are referred to as mul, and all people on a line of transactors beyond immediate partners can be designated by this term. This means the minimal transactional order for a kula relationship contains five nodes: two veiyou- on either side of ego and two - mul on each side of them. Hence -n-A-B-C-D-F-n. Kula action is realised in this structure. People participate in the system to make their names rise, to make the name seen. The hand of $\mathrm{F}$ that $\mathrm{D}$ gives to $\mathrm{C}$ makes $\mathrm{C}$ 's name go up. But when $\mathrm{C}$ gives this valuable to $\mathrm{B}$, B's name goes up and C's name goes down-the exact opposite of what is wanted. Only when B gives that valuable on to A does C's name go up and C becomes 'seen' or 'known' (kakin, a duplicated form of the verb 'see'; kin) or his 'fame/noise' (bulagan) is heard. Muyuw claim that control over the use of valuables follows this form. B may get a valuable from $\mathrm{C}$ with the stipulation that it go to a particular $A_{1}$. Various factors, however, may make $B$ give the valuable to a different person, $A_{2}$. In this situation, $\mathrm{C}$ may disallow the manoeuvre, force $\mathrm{B}$ to retrieve the valuable and do what he was supposed to do or just reclaim it himself, cancelling the initial transaction. People explained this distribution of responsibilities to me in the context of differences that exist in relationships, ked and paths held to be subsidiary to kula relationships. On large kula relationships, for example, pigs often flow back and forth. B might have received the valuable from $\mathrm{C}$ in part because he gave $\mathrm{C}$ a pig that he, $\mathrm{C}$, needed for 
a certain ritual. C may decide, however, to use the pig for a different ritual. This is not B's business and he cannot withdraw the pig. C, however, will still owe B a pig as a replacement, and would no matter what he did with the animal. The same relations prevail among all the subsidiary things exchanged beneath kula valuables. Their structure is effectively binary, whereas kula has the aforementioned five-part structure. The lower-level exchanges correlate with the organic division of labour symbolised by the firewood used for each place. By contrast, the vision of two circulating rings and the five-part form of every kula ked correlate with the encompassing structures, mythological and geographical, noted in the previous section.

As noted elsewhere (Damon 2002: 122-23), kula valuables are also thought to move up and down, not just left to right (mwal) and right to left (veigun). So, veigun, necklaces, go down from Muyuw to points south. They also go down from central Muyuw to southeastern Muyuw. Both vectors must involve a point of inversion, and one informant located that inversion near Iw, the small island between Muyuw and the Trobriands. I do not know how this spinning model relates to the southeasternnorthwestern axis. The region is, however, a complex topological space. And it should be recalled that, by string and other materials, especially as represented in the string figures that are basic cultural activities throughout this region (see Damon 2017: Ch.5), topological transformations are modes of thinking made common by various cultural practices.

The different ked of kula and its subsidiary spheres entail a reciprocal but asymmetrical ordering. Lower-level exchanges lead into and are usually for the productive order that is the kula - a method for producing ranked names. Just the same, some kula relationships are designed to gather the resources that are in the lower tiers. Their operation does not usually alter the nature and flow of kula valuables on specific paths, but they might. All lower-level spheres are defined, like kula, by being able to make or acquire, often, different things, the exchange of which is considered to be the exchange of equivalents. Equivalence here is abstracted into the idea of 'intentions', complementary though they usually are. By giving a partner a bundle of sleeping mats, the giver 'makes' (-vag) the intentions of the receiver. Following the giving of some article, the giver might say to the recipient 'you make your mind' (kuvag nanom), the clear implication being that the giver created the wherewithal for the receiver to follow his plans. This statement, however, is not often heard in kula exchanges because their intentions are usually finely specified before the exchange is made, all the more so when a specific article is a return gift and must 
follow the course of the initial debt-making item. So, when a receiver returns clay pots for mats he earlier received, he makes the original giver's intentions. This basket of yam tuber seeds is given for that bundle of taro stalks; the seeds for taro. One of the ways villages differentiate themselves is by their relative ability to withstand fluxes that come with El Niño/La Niña dynamics for which yams and taro have complementary strengths and weaknesses.

The primary purpose of the subsidiary exchanges is, overtly or covertly, the exchange of kula valuables as mwal (armshells) and veigun (necklaces). In the classic exchange literature (Bohannan 1955; Bohannan and Dalton 1962), this is two sets of conveyances designed so that the lower one converts into the higher one. Purposefully or not, sometimes a particular agent cannot return what he must. That can result in the creditor being able to claim an armshell or necklace as a kitoum, the short definition of which is a personally owned kula valuable. This alters the understanding of all the flowing objects but not necessarily the obligations those objects have created. If $\mathrm{B}$ can claim a valuable from $\mathrm{C}$ as his kitoum because of flows on subsidiary paths, $\mathrm{C}$ cedes the valuable to $\mathrm{B}$ whether or not it was his kitoum to begin with. If he takes the valuable as a kitoum, B does not owe $\mathrm{C}$ anything. However, $\mathrm{C}$ still carries the obligations of the valuable he had to give over, to some $\mathrm{D}$ and he owes a return to that $\mathrm{D}$. These kinds of intricacies are understood as the rules that go along with the content of these unique but intermingling ked. As is the case in many Austronesian societies, degrees of precedence and the recognition of variability flow within and between the ranked exchange spheres (Fox 1999).

As the global understandings of kula transactions rest upon important and sometimes determining relationships beneath them, so the idealised exchange of women, or men, depicted in the model of kum (clans) in the Muyuw garden contains a series of subsidiary paths. Foremost among these is the exchange of pigs in the primary Muyuw mortuary relationship, sagall anagin tavalam. In this ritual, if a man gives his wife's father, mother's brother or brother a live pig for a mortuary ritual when he puts on one of these rituals, it is expected that they will give him a live pig in return. Various other things - such as sticks draped with cloth, tobacco, money and betel nuts, units of sago and baskets of yams and taro-go along with the pig in these exchanges. They, too, are to be returned but, unlike the pigs, they are not counted against the flow of resources-garden land, sago orchards-that pass back and forth in place of missed pig returns. If the exchange of women and men between the clans is largely an ideal 
that resembles reality only after the fact, the exchange of pigs of identical size and sex is real, counted, measured and has consequences. However, while often phrased in terms of the ritual of the Kubay, Kwasis or Sinawiy kum, in fact the unit holding the debt is really a subclan (dal) and, within that, usually a more narrowly configured line of people.

Beneath the real exchange of pigs are several other ked, which, while analogised with the two above it, in fact carry different names, forms and purposes. Moreover, while they involve exchanges, their point is not the replacement of this with that but the enabling, rewarding or reproducing of productive capacities. They articulate the real relationships marriages define. A generic term for many of these ked —and here a translation like 'transferral' is more apt than 'path' or 'road'-is takon, of which there are many kinds. I briefly describe two.

When couples are first married, they usually reside with the wife's family. If children result, they are usually kept by the wife's mother and father because in this context the wife is considered the husband and the husband, the woman. To be made a man, the husband's father must take the couple to his house. He then becomes the man, with his wife only implicitly a woman. Formally, this transferral is accomplished by imposing a kula relationship over the married couple that runs through the husband's and wife's parents, and they in fact are the active agents in the exchange, though the young couple may take it over and turn it into a significant kula relationship. A woman only becomes a real woman, which means formally separated from but tied to her brother, by means of a large takon, often three or more years into their marriage. All takon entail the exchange of female things for male things. Female things include pigs, vegetables including raw yams and taro and sometimes cooked sago pudding or munowun, which is the culture's most prestigious dish. ${ }^{25}$ Male things consist of axes, machetes, knives, now money and, in a specific context, kitoum. These are not, however, just female and male things. They are means of consumption on the one hand and means of production on the other, hence the gendering. In the specific takon that makes a woman a wife, her brother raises a large pig and, at the appointed time, kills it and gives it, partially butchered, with baskets of yams and taro-the corm separated from its stalk, which is kept by the giver-to his sister and through her to her husband, his brother-in-law (nubou-). The partially

25 Cooked taro is pounded flat then rolled up and recooked in clay pots full of coconut cream. 
butchered pig emphasises that the female things given in this context are means of consumption. Were the pig given lives, it might go into some other circuit. Here its use-as with the cooked and raw yams and tarois only to be eaten. Moreover, a special piece of pork, often a forearm, goes to the sister's husband's father in honour of his having produced the husband. For the brother's female things-means of consumption-he receives tools, which are obviously means of production. This exchange stresses the complementary differences between men and womenorganisers of production on the one hand and of consumption on the other. The difference is deeply embedded in the mores of these exchanges. For, after this successful exchange, and only after it, a husband is bound to give a kitoum to his wife's subclan mates when she dies. Such kitoum might be given to a living brother-in-law or a man's children, both of whom are in the deceased wife's dal. One man told me that a subclan is like a bank; I asked him what was in the bank and he said 'kitoum'. In saying this, he was referring to the process that turns sisters into kitoum — male things.

Various kinds of takon run the length of what could be called the Muyuw domestic cycle. Earlier I noted that when a woman first marries, she has to deliver appropriate firewood to all of the elder women related to her new husband. Those exchanges are takon; for each bundle of firewood (means of consumption), some male thing needs to be given. These are now usually small pieces of monetary currency. As such, these exchanges are context markers. People say that his female relatives will not help a man when he has (mortuary) ritual obligations to his wife if, at the beginning of their marriage, the wife has not delivered firewood to these people. This lowerlevel takon sets up higher-level exchanges. The last takon in a marriage comes in a ceremony called a loun. Its performance is sometimes coupled with an anagin tavalam. The latter serves to put a new person in the place of a deceased. In conducting this ritual, a man literally takes over the deceased's debts and credits. The lo'un has a different purpose. It pays off the debt the deceased's father created when he made the deceased. With one exception, it operates like all takon. Matrilineal kin of the deceased assemble female things and give them to the matrilineal kin of the deceased's father. For those female things, male things are returned. The exception to the standard takon is that in at least one large container or stack of food are yams meant to be taken as seeds, not consumables. In one case, the point was emphasised by placing a whole taro-corm and stalk-with one prominent leaf hanging out, on top of the pile of yams. In all other ritual contexts when taro is given, the stalk is kept by the giver 
as a means of production. In this case, because the exchange is deemed to end the debt derived from the deceased father's productivity, what is returned are the means of production for male capacities. Although the deceased's father's marriage ended from his wife's point of view when she was replaced with a kitoum, it only ends with that father when his capacities have been refurnished. Nominally, that vegetable given as food should also have male things returned for it, and I was told that for a big pile of food a kitoum would be appropriate. I think, however, that this does not regularly happen and in one specific case for a 1974 lo'un the kitoum had not been turned over by 1982 .

As Muyuw array their ked related to marriage practices, takon rank below the ideal exchange of same-sex persons in the marriage model and the somewhat more real exchange of pigs for the primary mortuary rites. But more than just ranking is entailed. In the exchange-of-person model, the same things are exchanged: this female, or male, takes the place of that female, or male. The same holds for the exchange of pigs: like genders and sizes are exchanged and the sizes are measured. In both these exchanges, the genders are separated. Takon are different. Qualitatively different things are exchanged and they are realised in the differential capacities of the different genders. Effectively, they are not exchanges or transferrals; they are, and effect, transpositions. ${ }^{26}$ Such relations are microcosmic instances of the real division of labour that exists among the places in the Kula Ring. And removed from the synthetic model of interclan marriages, Muyuw people will readily specify certain kinds of marriages betweenor within-villages to take advantage of their differentiated duties.

The lowest-ranking ked concerns betel nut and betel pepper; and not just $k u l a$, but also courting prototypically start with these two. Yet they are not so much exchanged as they entail a complementary combination. And although nuts are considered female while pepper is male, in courting relationships, either gender may have the male or female item. And the encounter works by each person giving some of what they have while receiving the complement from the other person. Customarily, everyone in Muyuw carries their own supply of lime (pwakau), ${ }^{27}$ so it is added to

26 Many thanks to James J. Fox for carefully following through these data and suggesting the idea of 'transposition' for the ultimate translation of takon.

27 This word is also used for the colour white. Semen is pwak and the slide in meanings here is a matter of everyday consciousness. 
the other two so they become red and tangy. The differences are combined to become one entity, and this becomes a metaphor for the idealised relationship between couples moving to a successful marriage.

These spheres constitute a set defined by the idealised exchange of separated males and females at the top, in the depiction of men and women exchanged between clans (kum) to not so much the exchange but rather the combination of male and female qualities of betel nuts and pepper at the bottom.

And the characteristics of this set are witnessed in the euphemisms employed when asking somebody for something-in a sense, initiating a particular ked. When I asked why these procedures were employed, I was told because you want to avoid 'startling' somebody as well as give them room to manoeuvre around the request. From bottom to top, these references display a movement from far away from to part of a person. ${ }^{28}$

To request betel nut or betel pepper from someone, you ask for a kapon or giyag. Kapon is a half or quarter of a betel nut implicitly so forgotten or lost in the crevices of one's purse that it has rotted. Giyag literally means 'withered', but in this case it references a piece of betel pepper leaf or fruit forgotten and dried or rotten in one's purse. The idea in both these cases is that the things are completely out of mind. If yams are requested, one asks for those that were so small they fell through the floor of the yam house when it was being loaded for storage for the next year or that, when dumped out of the basket in which they were put from harvesting, were so small they were never loaded to begin with. Taro reproduce by new plants budding off the corm of the original seed stalk. The original stalk is almost always replanted, because it gets bigger over the years and a new corm will be proportionate to the size of its originating seed. When a plant is harvested, decisions are always made about which buds are large enough to be gathered and used as new seeds. Unless one is emerging from a drought that has drastically reduced one's taro stock (which was the case across much of Muyuw following the ENSO event of 1972-73), some of the new buds are ignored and left in the ground because they are too insignificant to plant. Those are the ones people ask for if they are in need of a resupply of taro seeds. For clay pots, one asks for shards from a broken pot that might still be large enough to use for minor cooking. If one wants a pig, the requests refer to the owner's door (kokwed). This follows because 
people feed their pigs — sometimes every morning and evening — at their doors. In the morning or evening, standing amid anxious pigs, people can be seen prying coconut meat out of split coconut shells. So, 'how is your door?' means 'do you have a pig to give me?'. ${ }^{29}$

Although an inversion characterises it, asking for a kula valuable climaxes this sequence. For all of these other items, the suitor asks for something. And although he asks for something metonymically connected to the person receiving the request, he expects to either be refused or be given something substantial. Kula requests are different. The suitor does not ask for something; instead, he commands the person holding the desired valuable to 'go think' (kun kunuway, igau mobaw: 'you go away, you think, then later I will come to you').

This sequence epitomises many of the ideas carried by the Muyuw understanding of the word ked, for the word carries an ethics of appropriate manners and methods. Although the desire for betel nut and betel chewing is ubiquitous, everyone realises that these are insignificant items, at best the beginning of other forms of sociality. Hence the request is for something completely forgotten. It is the same with the miniature yam seeds and unused taro seeds. But having both of these signals the capacity to manage Muyuw gardening practices with all of their overt cosmological orientations. The next step, doors for pigs, is even closer to a moral agent: somebody who has a house (young unmarried people do not and even young married people usually reside with parents or in-laws) and the wherewithal to maintain resources capable of supporting pigs, which are the primary debt-carrying vehicle for $d a l$ (subclan) resources. Having a 'door' means you have the resources-larger gardens in central Muyuw, coconut trees/plantations most everywhere else or ties to the Budibud pig-production sites - to maintain and produce other significant relations. The last metonym in this sequence intensifies these relations by invoking the human capacity for intentionality, for planning, keeping things straight, being a responsible person and, eventually, an elder. Unlike the betel nut request for something completely forgotten, the kula

29 The metonym 'door' for 'house' concerning pigs harkens to the symbolism of houses and marriage relations in China. The character for house (jiā), 家, comprises two others: one, $r$ (mián), which is translatable as 'roof', and the other, 豕 $(s h \grave{l})$, as pig. Pigs regularly figured in Chinese marriages as well. I thank Peng Xinyan for discussing these matters. 
invocation implicates what should be a part of a responsible person. ${ }^{30}$ And those responsible persons add up to other relations, with the signs of that summation being their kula valuables, their debts and credits and their names linked by ked to the distant places in the complex geography of the Kula Ring.

\section{References}

Blust, Robert A. 2009. The Austronesian Languages. Pacific Linguistics series. Canberra: Research School of Pacific and Asian Studies, The Australian National University.

Bohannan, Paul. 1955. 'Some principles of exchange and investment among the Tiv.' American Anthropologist 57: 60-70. doi.org/10.1525/aa.1955.57.1. 02a00080.

Bohannan, Paul and George Dalton, eds. 1962. Markets in Africa. Evanston, IL: Northwestern University Press.

Damon, Frederick H. 1980a. 'The Kula and generalised exchange: Considering some unconsidered aspects of the elementary structures of kinship.' $M A N(\mathrm{NS})$ 15(2): 267-93. doi.org/10.2307/2801671.

Damon, Frederick H. 1980b. 'The problem of the Kula on Woodlark Island: Expansion, accumulation, and overproduction.' Ethnos 45: 176-201. doi.org/ 10.1080/00141844.1980.9981198.

Damon, Frederick H. 1983a. 'Muyuw kinship and the metamorphosis of gender labour.' $M A N$ (NS)18(2): 305-26. doi.org/10.2307/2801437.

Damon, Frederick H. 1983b. 'The transformation of Muyuw into Woodlark Island: Two minutes in December, 1974.' The Journal of Pacific History 18(1): 35-56. doi.org/10.1080/00223348308572457.

Damon, Frederick H. 1983c. 'What moves the Kula: Opening and closing gifts on Woodlark Island.' In J.W. Leach and E.R. Leach, eds, The Kula: New perspectives on Massim exchange, pp. 309-42. Cambridge: Cambridge University Press.

30 Because animals — pigs, dogs, cats and so on-do not have minds, they commit incest. People who do not behave correctly_prototypically, young people (and small unnamed kula valuables)_are said to not have minds (teivag ninous). 
Damon, Frederick H. 1989. 'The Muyuw Lo'un and the end of marriage.' In Frederick H. Damon and Roy Wagner, eds, Death Rituals and Life in the Societies of the Kula, pp. 73-94. DeKalb, IL: Northern Illinois University Press.

Damon, Frederick H. 1990. From Muyuw to the Trobriands: Transformations along the northern side of the Kula Ring. Tucson, AZ: University of Arizona Press.

Damon, Frederick H. 1993. 'Representation and experience in kula and western exchange spheres (or billy).' Research in Economic Anthropology 14: 235-54.

Damon, Frederick H. 2002. 'Kula valuables, the problem of value and the production of names.' L'Homme 162: 107-36. doi.org/10.4000/lhomme.158.

Damon, Frederick H. 2017. Trees, Knots and Outriggers: Environmental knowledge in the northeast Kula Ring. Oxford: Berghahn Books. doi.org/10.2307/j.ctvs wx6vz.

Damon, Frederick H. 2018. 'Further notes on Kula Ring calendrics and megaliths? Towards an archaeology of Austronesian East Asian connectionsShort communication.' Global Journal of Archaeology \& Anthropology 5(1): 555654. doi.org/10.19080/GJAA.2018.05.555654.

Dorofeeva-Litchmann, Vera. 1995. 'Conception of terrestrial organization in the Shan Hai Jing.' Bulletin de l'Ecole française d'Extrême-Orient 82: 57-110. doi.org/10.3406/befeo.1995.2297.

Fox, James J. 1999. 'Precedence in practice among the Atoni Pah Meto of Timor.' In Lorraine V. Aragon and Susan D. Russell, eds, Structuralism's Transformations: Order and revision in Indonesian and Malaysian societies, pp. 3-36. Program for Southeast Asian Studies Monograph Series. Tempe, AZ: Arizona State University Press.

Godelier, Maurice. 1999. The Enigma of Gift. Trans. by Nora Scott. Chicago: University of Chicago Press.

Granet, Marcel. 1973. 'Right and left in China.' In Rodney Needham, ed., Right and Left: Essays on dual symbolic classification, pp. 43-58. Chicago: University of Chicago Press.

Green, Roger and Andrew Pawley. 1998. 'Architectural forms and settlement patterns.' In Malcolm Ross, Andrew Pawley and Meredith Osmond, eds, The Lexicon of Proto Oceanic: The culture and environment of ancestral Oceanic society. Volume 1: Material culture, pp. 37-66. Pacific Linguistics series. Canberra: Research School of Pacific and Asian Studies, The Australian National University. 
Irwin, Geoffrey, Ben Shaw and Andrew McAlister. 2018. 'The origins of the Kula Ring: Archaeological and maritime perspectives from the southern Massim and Mailu areas of Papua New Guinea.' Archaeology in Oceania 54(1): 1-16. doi.org/10.1002/arco.5167.

Leach, Edmund. 1964. 'Anthropological aspects of language: Animal categories and verbal abuse.' In E. Lenneberg, ed., New Directions in the Study of Language, pp. 23-63. Cambridge, MA: MIT Press. doi.org/10.1037/e685262012-044.

Lepowsky, Maria. 1994. Fruit of the Motherland: Gender in an egalitarian society. New York: Columbia University Press.

Mosko, Mark S. 2009. 'Omarakana revisited, or "do dual organizations exist?" in the Trobriands.' Journal of the Royal Anthropological Institute (NS) 19: 482-509. doi.org/10.1111/1467-9655.12046.

Mosko, Mark S. 2017. Ways of Baloma: Rethinking magic and kinship from the Trobriands. Chicago: Hau Books.

Pankenier, David. 2013. Astrology and Cosmology in Early China: Conforming earth to heaven. Cambridge: Cambridge University Press. doi.org/10.1017/ CBO9781139017466.

Pawley, Andrew and Malcolm Ross. 1995. 'The prehistory of the Oceanic languages: A current view.' In Peter Bellwood, James J. Fox and Darrell Tryon, eds, The Austronesians: Historical and Comparative Perspectives, pp. 39-74. Canberra: Department of Anthropology, Research School of Pacific Studies, The Australian National University.

Piot, Charles D. 1991. 'Of persons and things: Some reflections on African spheres of exchange.' MAN (NS)26(3): 405-24. doi.org/10.2307/2803875.

Ross, Malcolm. 2008. 'The integrity of the Austronesian language family: From Taiwan to Oceania.' In Alicia Sanchez-Mazas, Roger Blench, Malcolm Ross, Ilia Peiros and Marie Lin, eds, Past Human Migrations in East Asia: Matching archaeology, linguistics and genetics, pp. 161-81. London: Routledge Curzon.

Strathern, Marilyn. 1988. The Gender of the Gift: Problems with women and problems with society in Melanesia. Berkeley, CA: University of California Press. doi.org/10.1525/california/9780520064232.001.0001.

Strathern, Marilyn. 1991. Partial Connections. Savage, MD: Rowman \& Littlefield.

Therik, Tom. 2004. Wehali: The female land-Traditions of a Timorese ritual centre. Canberra: Pandanus Books. 
This text is taken from Austronesian Paths and Journeys, edited by James J. Fox, published 2021 by ANU Press, The Australian National University, Canberra, Australia.

doi.org/10.22459/APJ.2021.10 